\title{
Prototipe Sistem Notifikasi Banjir Menggunakan Arduino Uno Dan Gsm Modul Untuk Warga Universitas Pembangunan Jaya Kampus Bintaro
}

\author{
Renintha Trianjani Susilo ${ }^{1}$, Muhammad Gibran ${ }^{2}$, Fathan Albar $^{3}$, Heny Ispur Pratiwi ${ }^{4}$ \\ ${ }^{1}$ Program Studi Informatika, Universitas Pembangunan Jaya, \\ renintha.trianjanisusilo@student.upj.ac.id \\ ${ }^{2}$ Program Studi Informatika, Universitas Pembangunan Jaya \\ muhammad.gibran@student.upj.ac.id \\ ${ }^{3}$ Program Studi Informatika, Universitas Pembangunan Jaya \\ fathan.albar@student.upj.ac.id \\ ${ }^{4}$ Program Studi Informatika, Universitas Pembangunan Jaya \\ heny.pratiwi@upj.ac.id
}

\begin{abstract}
The inundation stage that comes from rainfall at in and out access of campus Universitas Pembangunan Jaya (UPJ) to or from the Bintaro Xchange Mall ring road (precisely at Jalan Bhakti Karya) can reach out more than $35 \mathrm{~cm}$, that amount of elevation drowned half the normal diameter of a motorcyle tires, so that it could disrupt the fluence UPJ academic activity. A Prototype has been designed and built based of Arduino Uno microcontroller, GSM Module, and Water Level Sensor to provide notification for the residents of UPJ about the condition of water inundation stage at the access road through Text Message (SMS) registered system, so that the residents of UPJ not trapped in that area.

Keywords : Arduino Uno, GSM Modul, Water Level Sensor
\end{abstract}

\begin{abstract}
Abstrak : Tingkat genangan hasil curah air hujan di area akses masuk dan keluar kampus Universitas Pembangunan Jaya (UPJ) dari atau menuju lingkar jalan raya Bintaro Xchange Mall (tepatnya di Jalan Bakti Karya) bisa mencapai lebih dari 35 $\mathrm{cm}$, angka ketinggian tersebut sudah merendam separuh diameter ban motor ukuran normal, sehingga akan mengganggu kelancaran aktivitas akademik UPJ. Sebuah purwarupa sudah dirancang bangun berbasis mikrokontroler Arduino Uno, GSM Modul untuk membantu memberi notifikasi para warga UPJ tentang kondisi tingkat genangan volume airpada jalan akses tersebut melalui sistem SMS terdaftar, sehingga warga UPJ tidak terjebak di area tersebut.
\end{abstract}

Kata Kunci : Arduino Uno, GSM Modul, Water Level Sensor

\section{PENDAHULUAN}

Banjir dihasilkan oleh curah air hujan yang berlebihan akan mengakibatkan volume genangan air di satu area lebih tinggi dibanding area yang lain. Kondisi ini mengakibatkan aktivitas ekonomi dan akademik terganggu, baik penduduk yang berada di titik area banjir atau sekitarnya. Beberapa penelitian sudah dilakukan sebelumnya untuk mencari solusi yang tepat dalam mengatasi banjir di area masing-masing dengan menggunakan metodologi dan prototipe yang disesuaikan dengan kondisi geologi setempat, yang pada dasarnya adalah tindakan inovatif yang baik untuk penerapan teknologi komunikasi dan informasi untuk membantu umat banyak.

Penelitian untuk rancang bangun perangkat lunak dan keras contohnya sudah dilakukan merancang sistem mobile untuk notifikasi kondisi banjir (Satria et al, 2017), (Anindita et al, 2016 ) dalam bentuk SMS yang adalah hasil proses sistem mikrokontroler Arduino Uno atau Raspberry Pi dan GSM Modul. Prototipe 
yang sudah ada tersebut bisa menjadi basis penelitian dan pengembangan untuk penerapan berikutnya seperti notifikasi tanah longsor (Fernandez et al, 2016) dan peringatan dini bahaya banjir (Astuti et al, 2018).

Penelitian yang dilakukan sebelumnya tersebut memberikan usulan solusi dengan latar belakang masingmasing permasalahan yang dihadapi termasuk kondisi geografis, ekonomi dan budaya, serta teknologi yang ada. Maka project singkat ini dilakukan juga berdasarkan latar belakang kondisi kondisi tersebut untuk mengirimkan notifikasi ketinggian banjir pada titik akses keluar masuk kampus UPJ melalui jalan lingkar Xchange Mall Bintaro, sehingga bisa menawarkan sebuah solusi agar permasalahan yang mengganggu aktivitas akademik UPJ dan memberi ketidaknyamanan warga UPJ yang memakai akses jalan tersebut bisa teratasi.

\section{Perumusan Masalah}

Jalan Bakti Karya, Kelurahan Sawah Baru adalah titik lokasi yang menjadi obyek awal permasalahan penelitian dan sasaran hasil luaran penelitian yang dilakukan.

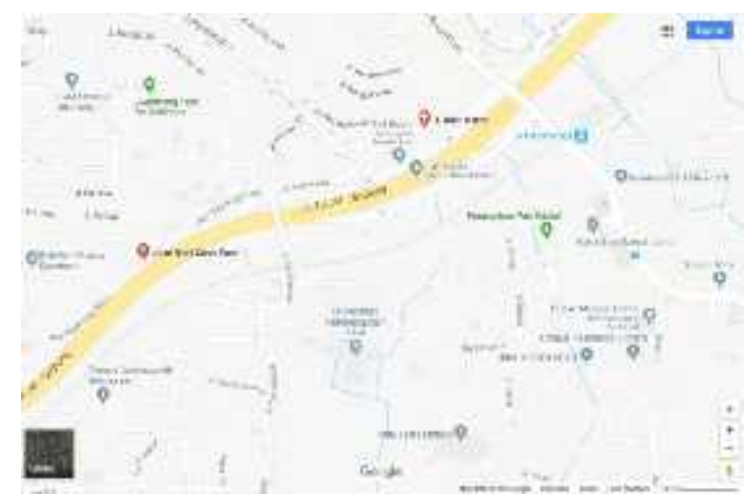

Gambar 1. Peta lokasi

(Google map)

Tingkat ketinggian air yang dianggap rawan adalah tingkat ketinggian yang sudah membahayakan warga untuk melewati titik lokasi tersebut, pada penelitian ini ketinggian $35 \mathrm{~cm}$ dipakai sebagai parameter patokan pengukuran tingkat bahaya banjir di titik lokasi tersebut. Parameter tersebut didapatkan dari pengukuran jarak antara dataran tanah dan knalpot sepeda motor dengan alasan mayoritas pengendara yang melewati titik lokasi tersebut adalah pengguna sepeda motor dan angka tersebut juga menguntungkan pengendara mobil sedan yang memiliki tingkat ruang yang rendah dari tanah.

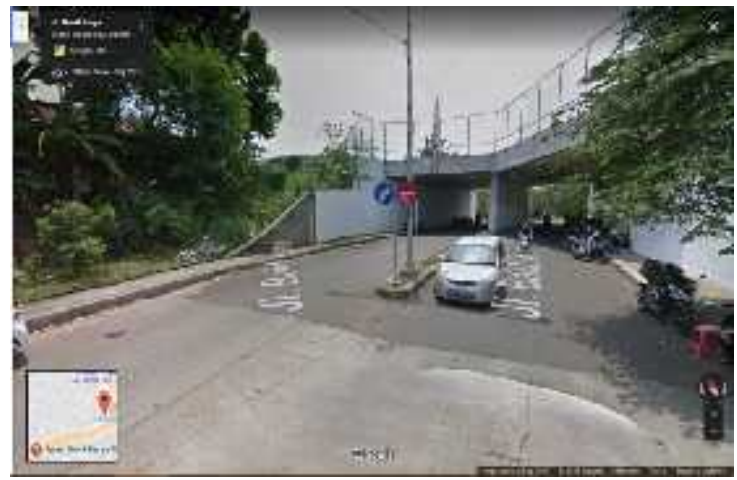

Gambar 2. Titik lokasi banjir (Google map)

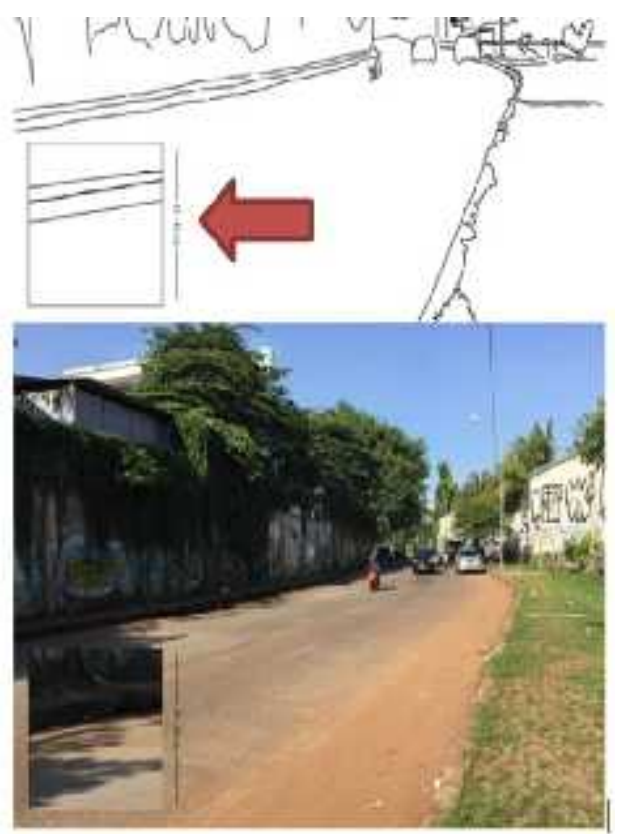

Gambar 3. Survey lokasi dan pengukuran tingkat ketinggian banjir

\section{Tujuan Penelitian}

Tujuan penelitian ini untuk menghasilkan luaran berupa sistem SMS terkirim sebagai sebuah notifikasi bahaya banjir ke nomor smartphone yang telah terdaftar atau terinput kedalam sistem. 
Luaran tersebut adalah hasil proses sistem mikrokontroler yang dirancang bangun dengan menggunakan Arduino Uno, Modul GSM GPS SIM808. Sistem menggunakan luaran berupa SMS agar pengguna yang tidak sedang menggunakan Internet dapat mengetahui situasi jalan yang terkena banjir. Selain itu, karena beberapa provider penyedia layanan internet biasanya mengalami gangguan jaringan saat terjadinya hujan, pengiriman SMS akan tetap dapat terlaksana walaupun terdapat pada jaringan 2G. Selanjutnya hasil penelitian ini diharapkan bisa menjadi dasar pengembangan dikemudian hari dengan menawarkan solusi yang lebih beragam dan tepat guna terhadap kompleksitas keberadaan masalah.

\section{Sistematika Penulisan}

Analisa perumusan masalah dilakukan untuk merespon keluhan warga UPJ tentang kondisi yang harus diperbaiki. Survey langsung ke lokasi area dilakukan untuk mengambil gambar dan mengukur estimasi tingkat ketinggian air di setiap sisi jalan dan angka rata-rata diambil untuk menjadi patokan sistem yang akan dirancang bangun. Analisa kebutuhan berikutnya adalah melakukan kajian pustaka untuk memenuhi segala kebutuhan perangkat yang diperlukan dan mengkaji cara pengujian sistem yang dirancang dengan kemungkinan respon yang bisa terjadi selama proses uji coba. Pemilihan metodologi yang dipilih adalah hasil dari kajian pustaka tersebut, Metodologi penelitian yang dipakai adalah yang sesuai dengan deskripsi urutan prosesi pengerjaan project, yaitu metode prototyping melalui SDLC (Software Development Life Cycle) (Nurasiah, 2014). Sedangkan sebelum tampilan hasil pengujian sistem, skema rancang bangun secara grafis dimunculkan untuk memberi gambaran pada pembaca tentang struktur rancangan sistem secara keseluruhan, dengan dsekripsi fungsional setiap komponen perangkat lunak dan perangkat keras secara garis besar. Kesimpulan adalah penutupan yang harus dilakukan untuk memunculkan kembali solusi yang sudah dihasilkan dari penelitian ini.

\section{KAJIAN PUSTAKA}

Penelitian ini juga merupakan hasil dari pengetahuan tentang teknologi otomasi yang terdiri dari perangkat keras dan lunak digunakan untuk rancang bangun desain yang sudah dianalisa berdasarkan survey lokasi.

Curah hujan yang cukup tinggi di Indonesia menyebabkan beberapa wilayah di Indonesia termasuk kedalam daerah rawan banjir. Selain karena luapan sungai, banjir terjadi karena genangan air hujan pada daerah kurang resapan, namun tidak adanya kabar yang pasti akan terjadinya banjir. Melihat fenomena banjir tersebut perlu dikiranya dibuat sebuah sistem tanggap bencana guna memberikan informasi secara cepat dan merata kepada seluruh warga akan datangnya banjir. Sistem berbasis SMS Gateway mampu bekerja secara optimal di area yang hanya terjangkau jaringan 2G, sehingga penerapan sistem ini dapat lebih akurat dalam pemberian kabar bencana langsung. (Riyadi et al, 2017).

SMS atau Short Message Service adalah teknologi yang awalnya hanya bisa mengirimkan pesan oleh pengguna dari satu telepon genggam ke telepon genggam yang lain, sekarang teknologi SMS dideskripsikan sebagai teknologi yang bisa dipakai pengguna tidak hanya antar telpon genggam tapi juga melalui komputer yang berfungsi sebagai SMS gateway dengan mengunduh aplikasi gateway tersebut terlebih dahulu. SMS bermanfaat bagi pengguna untuk mengirim atau menerima pesan dari satu atau lebih pengguna lain, pesan bisa berupa pesan pribadi, notifikasi, atau pesan yang bersifat emergency. SMS dianggap sebagai teknologi dan metode yang stabil dan memiliki banyak pengguna (Olaleye, 2013).

Berkembangnya aplikasi LBS (Location Based Service) atau Layanan berbasis Lokasi karena kebutuhan di setiap titik area lokasi berbeda dan beragam 
keberadaannya, sedangkan tuntutan masyarakat untuk mendapatkan layanan berbasis lokasi tersebut amat membantu kelancaran aktivitas mereka. Aplikasi LBS membutuhkan sistem GPS (Global Positioning System) untuk memberi luaran titik lokasi yang diinginkan terkirim melalui orbit satelit (Gintoro et al, 2010). Orbit satelit akan memberi luaran koordinat yang akan tampil di peta secara mobile system untuk memudahkan pengguna. Contoh yang paling banyak diakses dan digunakan adalah Google Maps yang menampilkan bukan hanya peta lokasi tapi juga teks, gambar, link serta menghubungkan ke aplikasi lain yang bertautan dengan tampilan. Google Maps menjadi terapan untuk LBS untuk mencari titik area lokasi tujuan (Santi, 2010). LBS sudah menjadi banyak basis pengembangan teknologi mobile (Woodrow, et al, 2008).

Adapun beberapa penelitian yang mengemukakan tentang penggunaan sensor untuk mendeteksi tingkat ketinggian air, contohnya dengan peralatan sensor ultrasonik yang bekerja berdasarkan pantulan gelombang suara dan memantulkan kembali dengan selisih waktu sebagai tingkat sensitifitas alat tersebut, selisih waktu antara menerima dan memantulkan kembali gelombang suara berbanding lurus dengan jarak atau tinggi objek yang memantulkan. Sedangkan objek yang di deteksi bisa berupa benda padat, cairan dan butiran (Ariyani et al, 2017).

\section{METODOLOGI PENELITIAN}

Metode eksperimental adalah metodologi yang dipakai dalam penelitian ini. Dimulai dari proses perumusan masalah, survey lokasi, studi pustaka, perancangan sistem perangkat lunak dan perangkat keras, tahap pengujian, analisa hasil pengujian dan melakukan dokumentasi seluruh proses (Ariyani et al, 2017). Dalam proses perancangan perangkat lunak yang diaplikasikan pada perangkat keras dilakukan proses yang disebut SDLC (Software Development Life Cycle) atau dideskripsikan sebagai siklus pengembangan perangkat lunak yang didalamnya terdiri atas siklus proses analisis, desain, implementasi, testing dan pemeliharaan (Nurasiah, 2014).

\section{HASIL PENELITIAN DAN ANALISIS}

Sebelum penyajian data hasil penelitian ini dilakukan, berikut adalah deskripsi pada tahap pengujian pertama keseluruhan sistem yang di rancang bangun untuk melihat pembetulan selanjutnya dan pengujian kedua adalah hasil dari pembetulan pengujian pertama.

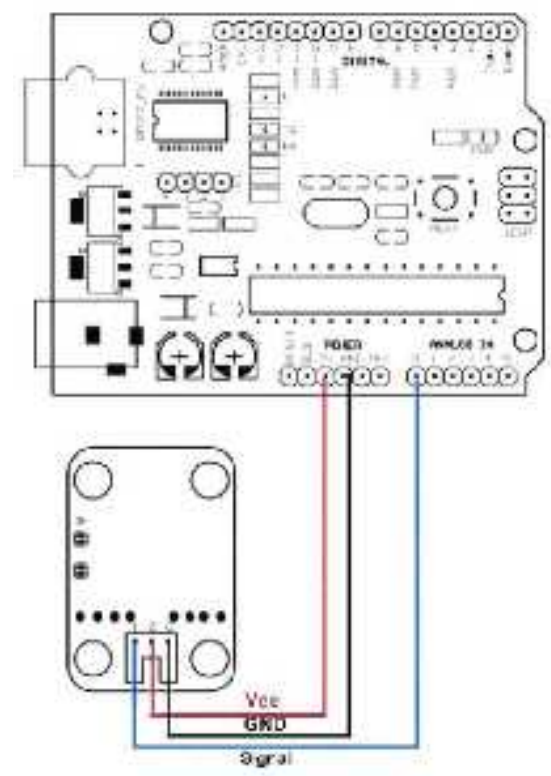

Gambar 7. Skema Rangkaian Arduino dan Water Level Sensor

(http://www.emarteem.com/product/42285) 


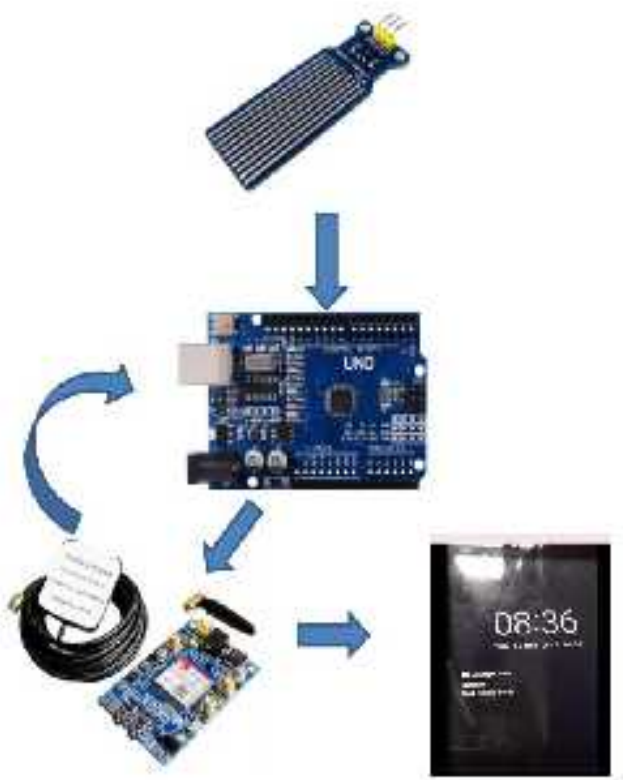

Gambar 8. Skema rangkaian sistem keseluruhan sistem

Sedangkan konstruksi tingkat ketinggian air banjir menggunakan pipa paralon 3 inch dan melekatkan tiga water level sensor di angka tingkat ketinggian yang berbeda, yaitu $25 \mathrm{~cm}, 30 \mathrm{~cm}$, dan $35 \mathrm{~cm}$ serta GSM GPS SIM808 untuk mengirimkan peringatan berupa SMS. Dalam memberikan SMS peringatan, peneliti membagi tingkat ketinggian air menjadi 3 level, yaitu level pertama ketinggian $25 \mathrm{~cm}$, alat akan mengirimkan sms peringatan kepada pengguna untuk berhati-hati dalam melewati jalur yang terkena banjir dengan ketinggian tersebut. Sementara level kedua untuk ketinggian $30 \mathrm{~cm}$, alat akan mengirimkan SMS peringatan yang sama yaitu untuk berhati-hati. Dan level terakhir, apabila ketinggian air sudah mencapai 35 $\mathrm{cm}$ atau lebih, SMS peringatan yang dikirimkan berbeda dari sebelumnya yaitu pengguna dihimbau untuk melewati jalur alternatif karena sudah tidak memungkinkan lagi pengendara untuk melewati jalur tersebut.

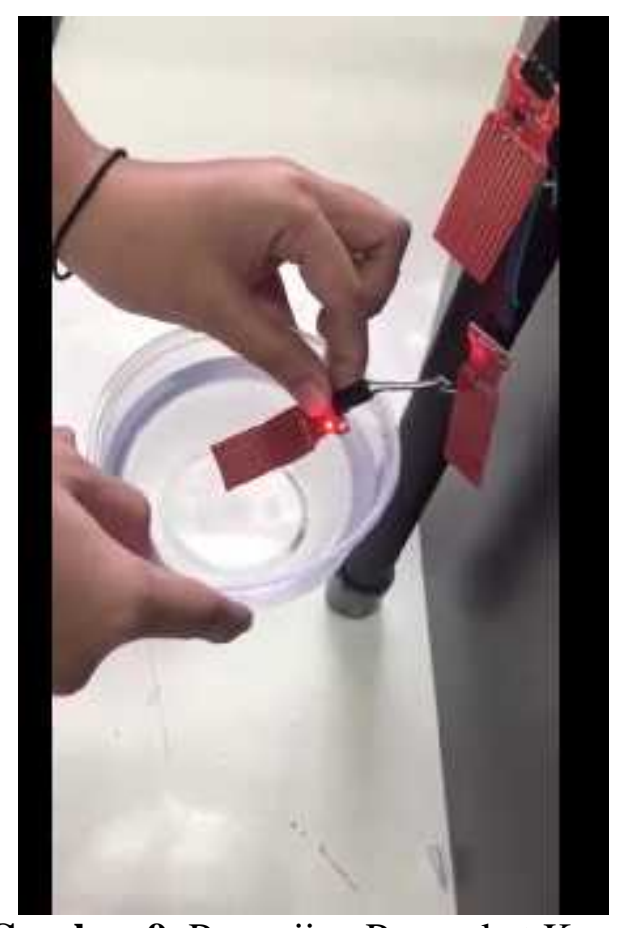

Gambar 9. Pengujian Perangkat Keras 
Tabel 1. Hasil Pengujian 1

\begin{tabular}{clll}
\hline No & \multicolumn{1}{c}{ Subjek } & \multicolumn{1}{c}{ Hasil } & \multicolumn{1}{c}{ Catatan } \\
\hline $\mathbf{1}$ & $\begin{array}{l}\text { Pengujian } \text { water } \\
\text { level sensor }\end{array}$ & Berhasil & Hanya 1 sensor \\
\hline $\mathbf{2}$ & $\begin{array}{l}\text { Inisialisasi } \\
\text { koneksi GSM } \\
\text { Module }\end{array}$ & Berhasil & \\
\hline $\mathbf{3}$ & GPS Activation & Gagal & Tidak terbaca \\
\hline $\mathbf{4}$ & GPS Activation & Berhasil & $\begin{array}{l}\text { Membutuhkan waktu } \\
\text { yang cukup lama }\end{array}$ \\
\hline $\mathbf{5}$ & $\begin{array}{l}\text { Pengujian 3 } \\
\text { water level } \\
\text { sensor }\end{array}$ & Gagal & $\begin{array}{l}\text { Hanya membaca sekali } \\
\text { dan membaca kembali } \\
\text { setelah sensor }==\text { false } \\
\text { dengan counter. }\end{array}$ \\
& $\begin{array}{l}\text { Counter tidak berfungsi } \\
\text { dengan Nested if }\end{array}$ \\
\hline $\mathbf{6}$ & $\begin{array}{l}\text { Pengujian 3 } \\
\text { water level } \\
\text { sensor }\end{array}$ & Berhasil & $\begin{array}{l}\text { Mengganti counter } \\
\text { dengan parameter } \\
\text { pembanding }\end{array}$ \\
\hline $\mathbf{7}$ & $\begin{array}{l}\text { GSM module } \\
\text { mengirim pesan }\end{array}$ & Berhasil & \\
\hline
\end{tabular}

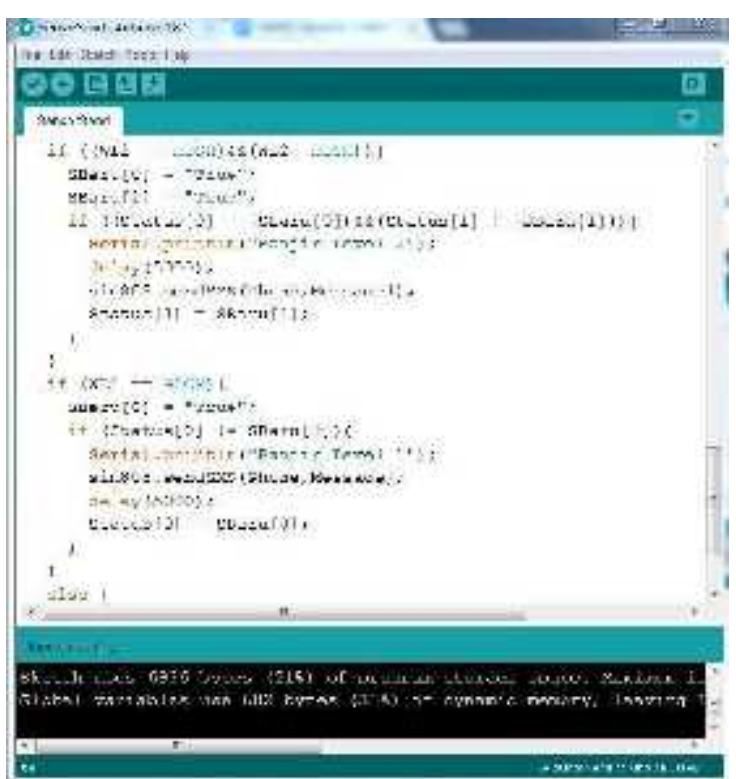

Gambar 10. Koding setelah pengujian 1

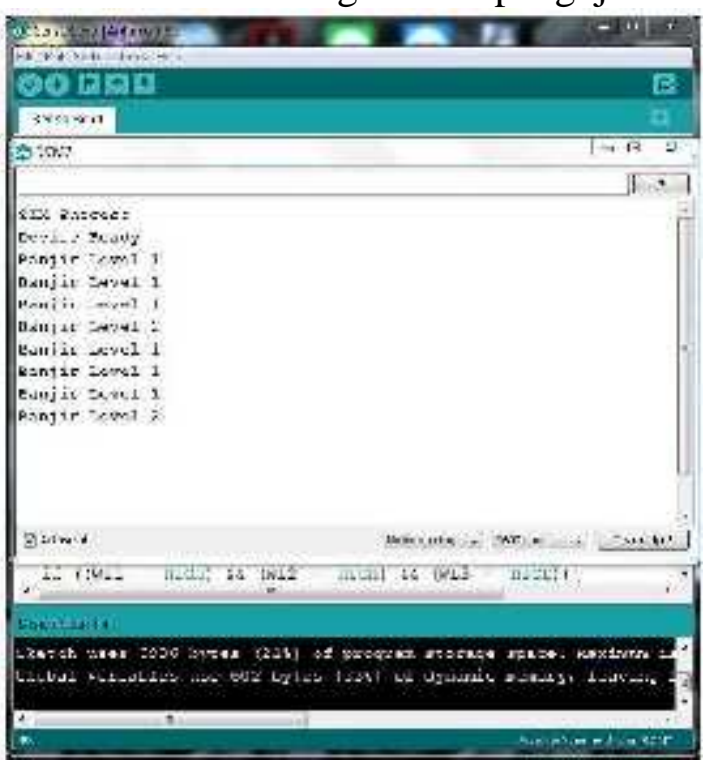

Gambar 11. Hasil Pengujian 2

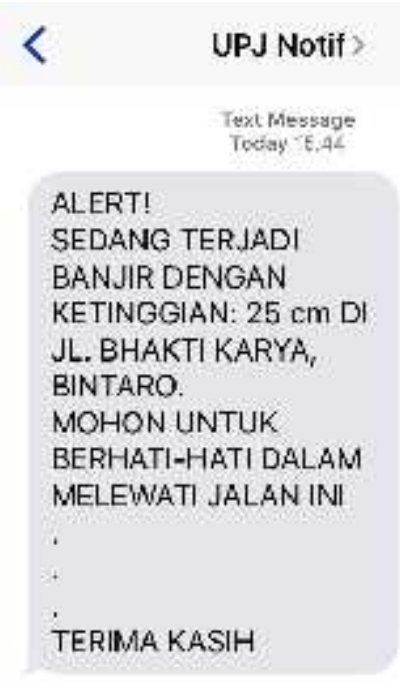

(O) (A) Toxt Message (1)

Gambar 12. Tampilan 1 di layar smartphone
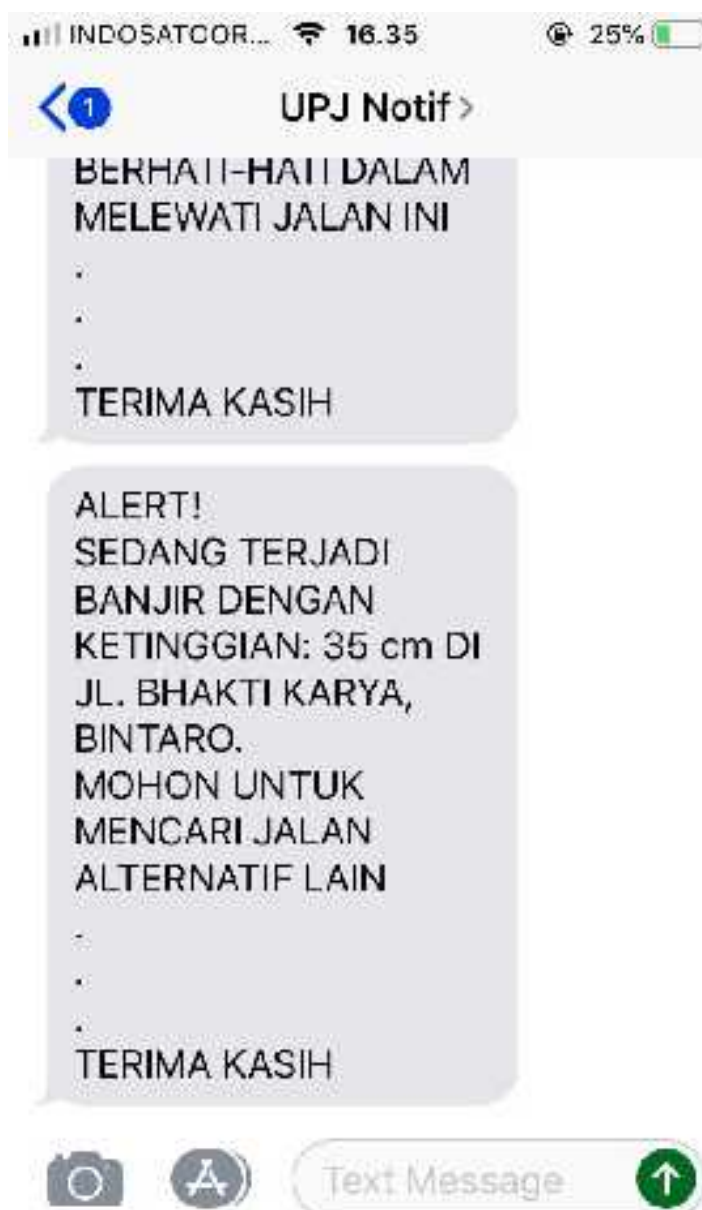

Gambar 13. Tampilan 2 di layar smartphone 
Terlihat dalam tabel 1 hasil pengujian pertama tidak memunculkan hasil luaran yang adalah disebabkan oleh sensitifitas yang tinggi dari perangkat sensor yang digunakan, yaitu sensor tersebut tidak akan merespon bila jari tangan penguji menyentuh bare conducting wires yang terdapat pada papan sensor. Solusi yang dilakukan adalah dengan memakai penjepit pada papan plastik sensor tersebut atau dengan tidak menyentuh bare conducting wires tersebut.

\section{KESIMPULAN}

Berdasarkan hasil dari pengujian yang dilakukan terhadap keseluruhan sistem yang sudah dirancang bangun, maka bisa disimpulkan bahwa sistem tersebut sudah menghasilkan luaran seperti yang dirancang untuk memberi luaran yang diharapkan, yaitu sistem notifikasi sudah terkirim ke smartphone terdaftar pada tingkat ketinggian air yang ditentukan. Dengan rancang bangun menggunakan perangkat mikrokontroler Arduino Uno R3, GSM GPS SIM808 Modul dan Water Level Sensor sudah berhasil memberikan informasi kepada warga UPJ tentang tingkat ketinggian air hujan yang menyebabkan banjir di titik area jalan Bakti Karya sehingga menghindarkan para warga untuk terjebak di titik area tersebut dan bisa mencari akses jalan lain. Selanjutnya angka tingkat ketinggian tersebut bisa dirubah seperti yang dibutuhkan dengan kondisi yang ada.

\section{SARAN}

Pengembangan sistem yang sudah berhasil dirancang bangun tersebut bisa dilakukan dengan menambahkan sumber daya listrik dari panel surya dengan melihat kemungkinan perangkat sistem akan dipasang di titik lokasi area terbuka yang menerima radiasi sinar matahari yang cukup untuk terus menerus memberi sumber listrik untuk mengoperasikan sistem perangkat. Pengembangan berikutnya adalah dengan menambahkan sistem dengan memberi luaran yang lebih informatif yaitu contohnya notifikasi mawas banjir setelah berita cuaca dari badan meteorelogi setempat menyatakan perkiraan curah hujan yang berlebih di area yang disebutkan, sehingga notifikasi diterima warga lebih awal untuk membantu melihat akses jalan lain sebelum terjebak di waktu dan area banjir. Kemudian pengembangan dapat berlanjut dengan memperbanyak titik peletakan sensor di beberapa daerah bintaro dengan memanfaatkan GPS yang sudah tertanam pada SIM808 untuk memberikan titik koordinat lokasi dan dihubungkan dengan data center yang dimiliki UPJ.

\section{DAFTAR PUSTAKA}

1. Anindito K, Indriasari D, Yanita H., Pengembangan Aplikasi SMS Autosender dan SMS Autoresponder untuk Sistem Pemantauan dan Pencarian Relawan Penanganan Bencana dengan Basis Lokasi, Prosiding Seminar Nasional XI Sekolah Tinggi Teknologi Nasional Yogyakarta :Rekayasa Teknologi Industri dan Informasi, 2016.

2. Ariyani D.R., Zaini, Putri R.E., Sistem Monitoring Banjir Pada Jalan Menggunakan Aplikasi Mobile dan Modul Wi-Fi, Seminar Nasional Sains dan Teknologi, Fakultas Teknik Universitas Muhamadiyah Jakarta, November 2017.

3. Astuti, I.F., Manoppo, A.N., Arifin, Z., Sistem Peringatan Dini Bahaya Banjir Kota Samarinda Menggunakan Sensor Ultrasonic Berbasis Mikrokontroler Dengan Buzzer dan SMS , SEBATIK STMIK WICIDA, 2018.

4. Fernandez, C.D., Mendoza, K.J.A., Tiongson, A.J.S., Mendoza, M.B., Development of Microcontroller-based Landslide early warning system, In Region 10 Conference (TENCON), IEEE (pp. 3000-3005), 2016.

5. Hatekar, A., Bajaj, H., Nayar N., Parab S., Intelligent Vehicle System, International Research Journal of Engineering and Technology (IRJET), Volume 05, issue 04, April, 2018. 
6. Nurasiah, N., System Information Development Plan of Tuition Payment by SDLC Waterfall Method, Jurnal Ilmiah Teknologi dan Rekayasa, 2014.

7. Olaleye, Oludare, Olaniyan, A., Eboda, O., Awolere, A., SMS-Based Event Notification System, Journal of Information Engineering and Applications, Vol.3, No.10, 2013.

8. Product Descriptions. 2018. Diambil dari http://www.emartee.com/product/42285

9. Rakesh, N.S., Harish N.G., Saicharan R., Kumar P., Antony A.S., Assiting System for Deaf and Mute Using Arduino Lilypad and Accelerometer, International Journal of Advance Research, Ideas And Innovations In Technology, volume 3 issue 3, 2017.

10. Riyadi S., Rokhim A., Perancangan Aplikasi Tanggap Bencana Banjir Berbasis SMS Gateway di Desa Kedawung Wetan Pasuruan, Prosiding volume 4th SNATIKA, November, 2017.

11. Santi, Yani, Ahmad., Kebutuhan Basis Data Untuk Aplikasi Sistem Informasi Geografi Dalam Era Otonomi Daerah, Universitas Gajah Mada, Yogyakarta, 2010.

12. Satria D., Yana S., Munadi R., Syahreza S., Sistem Peringatan dini Banjir Secara Real-Time Berbasis Web Menggunakan Arduino dan Ethernet, Jurnal JTIK, 2017.

13. Woodrow, Stephen, Post, Location is Everything Balancing Innovation, Convenience, and Privacy in Location Based Technologies, 2008. 